\title{
THE EFFECT OF SELECTED FACTORS ON FRESHENING MILKING EFFICIENCY IN PRIMIPAROUS POLISH HOLSTEIN-FRIESIAN BLACK-AND-WHITE COWS
}

\section{WPŁYW WYBRANYCH CZYNNIKÓW NA EFEKTYWNOŚĆ ROZDAJANIA PIERWIASTEK RASY POLSKIEJ HOLSZTYŃSKO-FRYZYJSKIEJ ODMIANY CZARNO-BIAŁEJ}

Department of Animal Breeding and Product Quality Assessment, Poznań University of Life Sciences, Poland

${ }^{1}$ Computer Lab, Poznań University of Life Sciences, Poland

2 Department of Ruminant Science, West Pomeranian University of Technology, Szczecin, Poland

\begin{abstract}
Streszczenie. Wykazano istotny pod względem statystycznym wpływ pochodzenia ojca oraz wieku i masy ciała przy zacieleniu jałowic na efektywność rozdajania pierwiastek rasy polskiej holsztyńsko-fryzyjskiej odmiany czarno-białej. Największą mlecznością w okresie rozdajania charakteryzowały się córki buhajów pochodzących z Ameryki Północnej i pierwiastki, które zostały zapłodnione jako jałówki - w wieku powyżej 16 miesięcy życia oraz przy masie ciała powyżej $475 \mathrm{~kg}$. Najprawdopodobniej wysoki potencjał genetyczny bydła hf pochodzącego z Ameryki Północnej, przewyższający pod względem wydajności mlecznej odmiany europejskie, był związany z dłuższym okresem jego doskonalenia, co w połączeniu z poprawą lokalnych warunków produkcyjnych zapewniło uzyskanie najkorzystniejszych rezultatów. Wydaje się, że na mleczność w okresie rozdajania większy wpływ mają masa ciała i rozwój jałowic niż ich wiek przy zapłodnieniu. Aby skrócić fazę odchowu u młodzieży żeńskiej, zaleca się stosowanie w tym okresie bardziej intensywnego żywienia.
\end{abstract}

Key words: Polish Holstein-Friesian Black-and-White cattle, primiparous, milk yield.

Słowa kluczowe: bydło rasy polskiej holsztyńsko-fryzyjskiej odmiany czarno-białej, pierwiastka, wydajność mleczna.

\section{INTRODUCTION}

The amount, composition and quality of milk produced by cows depend on genetic and environmental factors as well as the physiological and health status of these animals. Genetic factors account for approx. $30 \%$ effects on the yield of milk. It is assumed that already at calving such environmental conditions need to be established, which at the adequate genetic potential after the first calving may promote high productivity, which is a good prognostic for milk yield in successive lactations. In the opinion of many researchers at present the genetic potential in terms of milk production markedly exceeds nutrition and management standards of dairy cattle.

Corresponding author - Adres do korespondencji: Ireneusz R. Antkowiak, Department of Animal Breeding and Product Quality Assessment, Poznań University of Life Sciences, Złotniki, Słoneczna 1, 62-002 Suchy Las, Poland, e-mail: irekantk@up.poznan.pl 
Nutrition of calves and heifers needs to provide an adequately balanced feed ration meeting energy and protein requirements. Excessive nutrition leads to extreme fat deposition in the mammary gland, reducing the development of grandular tissue, while energy intake with the feed ration below the energy requirement in growing heifers may result in delayed occurrence of the first oestrus. It is assumed that HF heifers should be inseminated at the age of approx. 15 months at a body weight of approx. $380-415 \mathrm{~kg}$, while at a satisfactory development of the organism (height at the withers 126-127 cm) an accelerated insemination at the age of 13-14 months is also admissible. A later insemination date ( $>15$ months) may be connected with increased rearing costs influencing the economic aspects of milk production. A significant role affecting milk yields of primiparous cows during the freshening period may also be played by their origin. Studies determining the relationship of selected factors with milk yields of primiparous cows are of considerable practical importance and their results may be useful in planning breeding programs in farms specializing in the production of raw milk.

The aim of this study was to determine the effect of origin of sire as well as age and body weight at fertilization of heifers on freshening efficiency in primiparous Polish Holstein-Friesian Black-and-White cows.

\section{MATERIAL AND METHODS}

Analyses were conducted in the years 2012-2014 on the Golina Wielka farm belonging to Hodowla Zarodowa Zwierząt Żołędnica Sp. z o.o. Experimental material comprised the population of 130 primiparous Polish Holstein-Friesian Black-and-White cows. Animals were kept in the freestall system with access to a run. Milkings were performed three times a day (at 8-hour intervals) in a herring-bone milking parlor. Nutrition of individual technological groups was standardized according to the INRA recommendations. Nutrition was based on feeds produced on the farm. The total mixed ration (TMR) system was used. Source data concerning experimental primiparous cows were collected from the SYMLEK computer system, the heifercow charts and records of the farm zootechnician.

In this study the analyses concerned the effect of the following factors: origin of sire (from Europe - 32 animals from Poland, France and Holland, and from North America - 98 animals from the USA and Canada), age at first fertilization ( $\geq 14$ months, 14.1-16.0 months and $>16$ months) and body weight at fertilization ( $\geq 425 \mathrm{~kg}, 425.1 \mathrm{~kg}-475 \mathrm{~kg}$ and $>475 \mathrm{~kg}$ ) on milking performance traits during the freshening period (from day 6 to day 120 of lactation). Milk yield of cows was characterized based on the average daily milk yield and total milk yield in terms of the four stages of lactation (the first from day 6 to day 30, the second from day 31 to day 60 , the third from day 61 to day 90 and the fourth from day 91 to day 120). Overall (from day 6 to day 120 of lactation) 14950 data sets on daily milk yield were collected. The analyses specified also the mean daily milk yield and total milk yield of primiparous cows throughout the entire freshening period.

Statistical analyses were performed using the $S A S^{\circledR}$ v. 9.4 statistical software package (2015). In order to calculate the basic statistical parameters the MEANS procedure was applied. Significance of the effect of experimental factors for milking performance traits in the freshening period from day 6 to day 120 of lactation was analyzed applying the multivariate analysis of covariance using the SAS - GLM v.9.4 procedure (2015) according to the following linear model: 


$$
y_{\mathrm{ijk} / \mathrm{mn}}=\mu+r_{\mathrm{i}}+s_{\mathrm{j}}+o_{\mathrm{k}}+\beta_{1} m_{\mathrm{l}}+\beta_{2} W_{\mathrm{m}}+e_{\mathrm{ijk} / \mathrm{mn}}
$$

where:

$y_{i j k l m n}$ - phenotypic value of a trait,

$\mu$ - population mean,

$r_{\mathrm{i}}$ - fixed effect of the year of calving $(I=1,2,3)$,

$s_{j}-$ fixed effect of the season of calving $(j=1,2,3,4)$,

$o_{k}$ - fixed effect of origin of sire $(k=1,2)$,

$\beta_{1}, \beta_{2}$ - partial coefficients of 1 st order linear regression;

$m_{1}-$ body weight at first calving,

$w_{m}-$ age at first calving,

$e_{\mathrm{ijklmn}}$ - random residual effect.

To provide a detailed comparison of object means several multiple comparisons were performed using the Duncan test. In order to illustrate changes in milk yield a fragment of the lactation curve was plotted for the period from day 6 to day 120 taking into consideration the country of origin of the sire, the cow's age and body weight at first calving.

\section{RESULTS}

Table 1 presents results concerning daily and total milk yields in the four lactation periods (in the freshening period), as well as the average daily and total milk yields from day 6 to day 120 of lactation in primiparous cows after bulls from Europe and North America. Statistical analysis showed a highly significant effect of the origin of the sire on average daily milk yields of primiparous cows after various sire groups. Only in the first phase of lactation (from day 6 to day 30 of lactation) more advantageous results were recorded for primiparous cows sired by European bulls in relation to daughters of sires from North America. In turn, the successive analyzed phases of lactation and in the entire freshening period greater milk yields were recorded for primiparous cows after North American sires. However, statistical differences between means were found in the period from 61 to 90 days of lactation (at $P \leq 0.05$ ) as well as from 91 to 120 days (at $P \leq 0.01$ ), and jointly for the entire freshening period (at $P \leq 0.01$ ). Figure 1 presents the course of the lactation curve concerning the daily milk yield during the freshening period in the population of primiparous cows, which were divided into groups in terms of the origin of the sire. Trends for the course of the curves are consistent with the results given in Table 1; however, we may observe greater variation in daily milk yields in primiparous cows sired by bulls from North America in relation to the group of cows after European bulls. This may result from the greater sensitivity to environmental factors in cows sired by North American bulls.

Table 2 presents results concerning the dependency between age at fertilization and milking performance of primiparous cows during the freshening period. It was shown that age at effective fertilization has a significant effect $(P \leq 0.01)$ on the obtained daily milk yields both in the analyzed periods of lactation and in the entire freshening period (from days 6 to 120 of lactation). 
Table 1. Milk yields of primiparous Polish Holstein-Friesian Black-and-White cows during the freshening period (from day 6 to day 120 of lactation) in terms of origin of sire

Tabela 1. Wydajność mleczna pierwiastek rasy polskiej holsztyńsko-fryzyjskiej odmiany czarno-białej w okresie rozdajania (od 6 do 120 dnia doju), przy uwzględnieniu pochodzenia ojca

\begin{tabular}{|c|c|c|c|c|c|c|c|c|c|}
\hline \multirow{3}{*}{$\begin{array}{c}\text { Period } \\
\text { of lactation } \\
\text { [days] } \\
\text { Okres laktacji } \\
\text { [dni] }\end{array}$} & \multirow{3}{*}{$\begin{array}{c}\text { Traits } \\
\text { Cechy } \\
{[\mathrm{kg}]}\end{array}$} & \multicolumn{8}{|c|}{$\begin{array}{c}\text { Origin of bull } \\
\text { Pochodzenie buhaja }\end{array}$} \\
\hline & & \multicolumn{4}{|c|}{$\begin{array}{l}\text { Europe } \\
\text { Europa }\end{array}$} & \multicolumn{4}{|c|}{$\begin{array}{c}\text { North America } \\
\text { Ameryka Północna }\end{array}$} \\
\hline & & $\bar{x}$ & SD & $\min$. & max. & $\bar{x}$ & SD & $\min$ & $\max$ \\
\hline & $\begin{array}{c}\text { daily milk yield } \\
\text { dobowa wydajność mleka }\end{array}$ & $33.7 \mathrm{~A}$ & 7.3 & 15.6 & 54.2 & $33.1 \mathrm{~A}$ & 7.9 & 7.4 & 57.9 \\
\hline $6-30$ & $\begin{array}{c}\text { total milk yield } \\
\text { łączna wydajność mleka }\end{array}$ & 841.3 & 150.8 & 548.7 & 1167.1 & 827.5 & 154.9 & 358.2 & 1211.1 \\
\hline & $\begin{array}{c}\text { daily milk yield } \\
\text { dobowa wydajność mleka }\end{array}$ & 38.2 & 6.8 & 16.3 & 58.6 & 38.7 & 8.1 & 11.8 & 64.5 \\
\hline $31-60$ & $\begin{array}{l}\text { total milk yield } \\
\text { łączna wydajność mleka }\end{array}$ & 1146.4 & 177.5 & 726.8 & 1557.9 & 1159.8 & 216.7 & 555.3 & 1708.3 \\
\hline & $\begin{array}{c}\text { daily milk yield } \\
\text { dobowa wydajność mleka }\end{array}$ & $39.3 \mathrm{a}$ & 6.7 & 21.2 & 56.9 & $39.9 \mathrm{a}$ & 8.2 & 10.8 & 64.8 \\
\hline $61-90$ & $\begin{array}{c}\text { total milk yield } \\
\text { łączna wydajność mleka }\end{array}$ & 1180.3 & 170.3 & 803.9 & 1491.3 & 1197.3 & 215.7 & 509.7 & 1661.7 \\
\hline & $\begin{array}{c}\text { daily milk yield } \\
\text { dobowa wydajność mleka }\end{array}$ & $38.9 \mathrm{~A}$ & 7.1 & 15.5 & 66.8 & $39.9 \mathrm{~A}$ & 8.7 & 9.9 & 69.6 \\
\hline $91-120$ & $\begin{array}{c}\text { total milk yield } \\
\text { łączna wydajność mleka }\end{array}$ & 1165.5 & 174.2 & 794.8 & 1523.1 & 1198.3 & 223.7 & 546.0 & 1818.3 \\
\hline & $\begin{array}{c}\text { daily milk yield } \\
\text { dobowa wydajność mleka }\end{array}$ & $37.7 \mathrm{~A}$ & 7.3 & 15.5 & 66.8 & $38.1 \mathrm{~A}$ & 8.7 & 7.4 & 69.6 \\
\hline $6-120$ & $\begin{array}{c}\text { total milk yield } \\
\text { łączna wydajność mleka }\end{array}$ & 4333.6 & 605.6 & 3071.9 & 5645.6 & 4382.8 & 744.2 & 1969.2 & 5975.9 \\
\hline
\end{tabular}

Means with the same letter (in rows) differ: $A, B, C-(p \leq 0.01) ; a, b, c-(p \leq 0.05)$ - Średnie oznaczone tymi samymi literami $(w$ wierszach) różnią się: $A, B, C$ ( $\leq 0,01)$; $a, b, c(p \leq 0,05)$ 
Table 2. Milk yields of primiparous Polish Holstein-Friesian Black-and-White cows during the freshening period (from day 6 to day 120 of lactation) in terms of age at first calving in their life

Tabela 2. Wydajność mleczna pierwiastek rasy polskiej holsztyńsko-fryzyjskiej odmiany czarno-białej w okresie rozdajania (od 6 do 120 dnia doju), przy uwzględnieniu wieku przy pierwszym zacieleniu w ich życiu

\begin{tabular}{|c|c|c|c|c|c|c|c|c|c|c|c|c|c|}
\hline \multirow{3}{*}{$\begin{array}{c}\text { Period of } \\
\text { lactation } \\
\text { [days] } \\
\text { Okres } \\
\text { laktacji } \\
\text { [dni] }\end{array}$} & \multirow{3}{*}{$\begin{array}{c}\text { Traits } \\
\text { Cechy } \\
{[\mathrm{kg}]}\end{array}$} & \multicolumn{12}{|c|}{$\begin{array}{c}\text { Age at first fertilization [month] } \\
\text { Wiek przy pierwszym zacieleniu [miesiąc] }\end{array}$} \\
\hline & & \multicolumn{4}{|c|}{$\leq 14$} & \multicolumn{4}{|c|}{$14,1-16,0$} & \multicolumn{4}{|c|}{$>16$} \\
\hline & & $\bar{x}$ & SD & $\min$. & $\max$ & $\bar{x}$ & SD & $\min$. & $\max$. & $\bar{x}$ & SD & $\min$. & $\max$ \\
\hline & $\begin{array}{c}\text { daily milk yield } \\
\text { dobowa wydajność mleka }\end{array}$ & $34.2 \mathrm{~A}$ & 6.8 & 17.4 & 51.8 & $32.6 \mathrm{AB}$ & 7.8 & 7.4 & 57.3 & $34.1 \mathrm{~B}$ & 7.9 & 8.9 & 57.9 \\
\hline $6-30$ & $\begin{array}{l}\text { total milk yield } \\
\text { łączna wydajność mleka }\end{array}$ & $855.6 \mathrm{a}$ & 145.2 & 613.5 & 1167.1 & $815.2 a b$ & 160.6 & 358.2 & 1211.1 & $852.2 \mathrm{~b}$ & 141.8 & 588.3 & 1161.7 \\
\hline & $\begin{array}{c}\text { daily milk yield } \\
\text { dobowa wydajność mleka }\end{array}$ & $39.4 \mathrm{AB}$ & 6.1 & 27.0 & 57.7 & $37.3 \mathrm{AC}$ & 7.5 & 12.0 & 60.0 & $40.5 \mathrm{BC}$ & 8.3 & 11.8 & 64.5 \\
\hline $31-60$ & $\begin{array}{l}\text { total milk yield } \\
\text { łączna wydajność mleka }\end{array}$ & 1182.9 & 163.0 & 959.5 & 1497.8 & $1119.4 \mathrm{a}$ & 199.3 & 555.3 & 1533.5 & $1216.0 \mathrm{a}$ & 220.9 & 700.4 & 1708.3 \\
\hline & $\begin{array}{c}\text { daily milk yield } \\
\text { dobowa wydajność mleka }\end{array}$ & $40.7 \mathrm{AB}$ & 6.3 & 27.3 & 60.3 & $38.1 \mathrm{AC}$ & 7.9 & 10.8 & 59.0 & $42.5 \mathrm{BC}$ & 7.5 & 18.1 & 64.8 \\
\hline $61-90$ & $\begin{array}{c}\text { total milk yield } \\
\text { łączna wydajność mleka }\end{array}$ & 1221.9 a & 163.7 & 1003.8 & 1561.6 & $1143.9 \mathrm{a}$ & 205.2 & 509.7 & 1550.6 & $1273.9 \mathrm{a}$ & 191.1 & 762.7 & 1661.7 \\
\hline & $\begin{array}{c}\text { daily milk yield } \\
\text { dobowa wydajność mleka }\end{array}$ & $39.8 \mathrm{AB}$ & 7.6 & 22.2 & 61.2 & $37.9 \mathrm{AC}$ & 8.0 & 9.9 & 66.8 & $42.8 \mathrm{BC}$ & 8.1 & 14.5 & 69.6 \\
\hline $91-120$ & $\begin{array}{l}\text { total milk yield } \\
\text { łączna wydajność mleka }\end{array}$ & $1193.9 \mathrm{a}$ & 202.4 & 922.6 & 1627.7 & 1137.8 Aa & 199.3 & 546.0 & 1476.8 & $1284.0 \mathrm{~A}$ & 210.3 & 726.5 & 1818.3 \\
\hline & $\begin{array}{c}\text { daily milk yield } \\
\text { dobowa wydajność mleka }\end{array}$ & $38.7 \mathrm{AB}$ & 7.1 & 17.4 & 61.2 & $36.7 \mathrm{AC}$ & 8.1 & 7.4 & 66.8 & $40.2 \mathrm{BC}$ & 8.7 & 8.9 & 69.6 \\
\hline $6-120$ & $\begin{array}{l}\text { total milk yield } \\
\text { łączna wydajność mleka }\end{array}$ & 4454.3 & 644.9 & 3687.7 & 5669.6 & $4216.3 a$ & 700.9 & 1969.2 & 5665.5 & $4626.2 \mathrm{a}$ & 682.3 & 2789.9 & 5975.9 \\
\hline
\end{tabular}

Means with the same letter (in rows) differ: $A, B, C-(p \leq 0.01) ; a, b, c-(p \leq 0.05)$ - Średnie oznaczone tymi samymi literami (w wierszach) różnią się: $A, B, C-(p \leq 0,01)$; $a, b$, $c-(p \leq 0,05)$. 


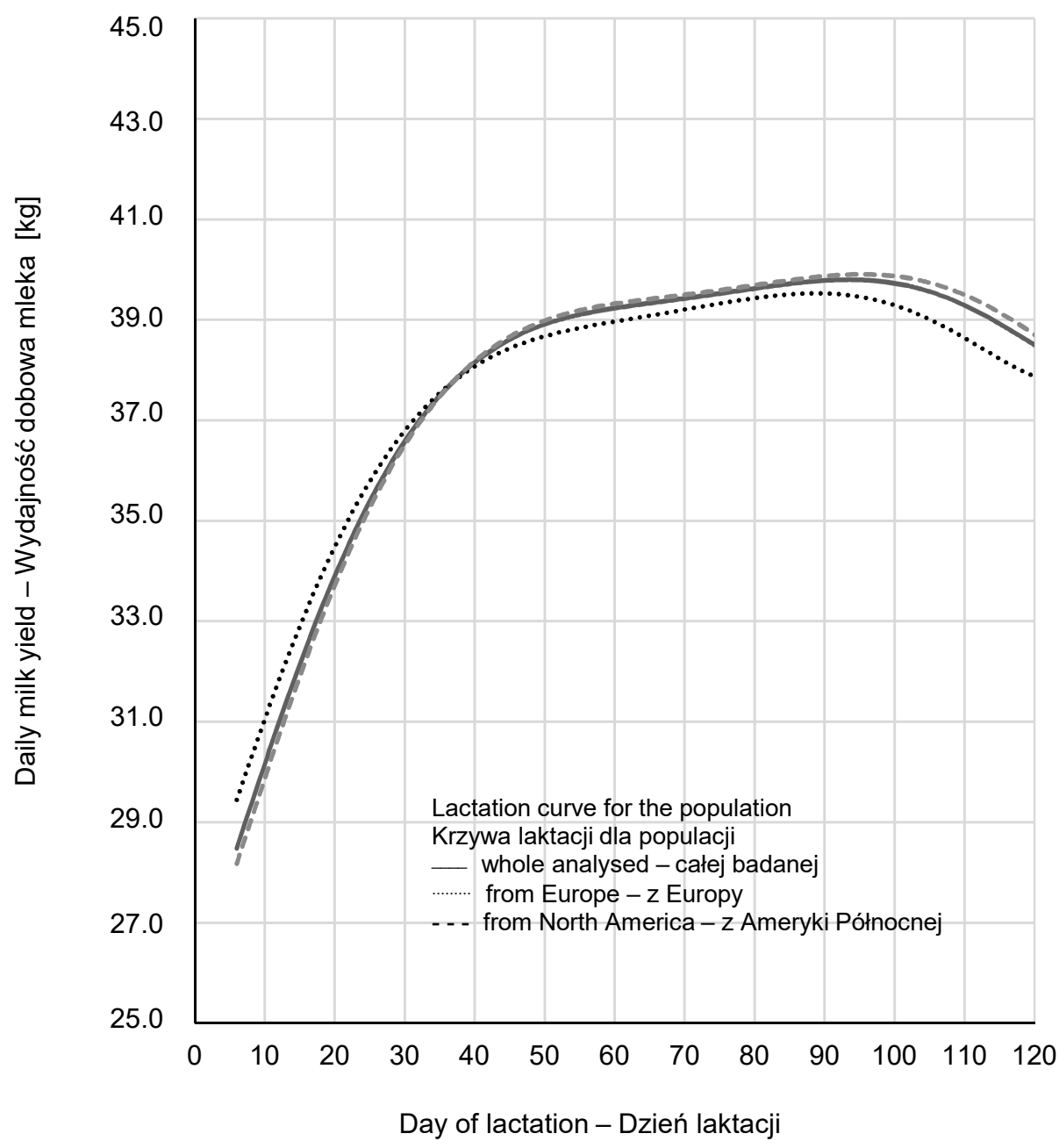

Fig. 1. Daily milk yield and the lactation curve for daily milk yield during the freshening period in primiparous Polish Holstein-Friesian Black-and-White cows in terms of origin of sire

Ryc. 1. Wydajność dobowa mleka i przebieg krzywej laktacji dla dobowej wydajności mleka w okresie rozdajania pierwiastek rasy polskiej holsztyńsko-fryzyjskiej odmiany czarno-białej, przy uwzględnieniu pochodzenia ojca

In terms of the average daily milk yield in individual lactation periods and in the entire analyzed lactation period the least advantageous results were recorded for primiparous cows, which age at first calving fell within the range of 14.1 to 16 months. In turn, the greatest daily milk yields, except for the first period of lactation (from day 6 to day 30 of lactation), were found for primiparous cows aged $>16$ months at effective fertilization. In terms of the above-mentioned trait, milk yield except for the milking period from day 6 to day 30 this group of primiparous cows differed (at $P \leq 0.01$ ) from the two other populations of animals. In terms of the total milk yields recorded for primiparous cows in individual periods of lactation the results were comparable to those for daily milk yields, although these dependencies were less marked (statistically fewer significant differences were found between the means and except for one case these means differed at $P \leq 0.05$ ). When analyzing the course of the lactation curve established for the daily milk yield taking into consideration the age of the cows at fertilization (Fig. 2) the greatest daily milk yield was found in relation to the entire population of heifers 
effectively inseminated at the age of over 16 months, while the course of lactation in the freshening period is highly advantageous. Practically up to day 97 of lactation the daily milk yield was increasing consistently and it was maintained on the uniform high level up to day 120 of milking. In this group of animals the course of the lactation curve for daily milk yield diverges markedly from the curves plotted for the other two groups of primiparous cows. When analyzing this graph in terms of the future milk yield it may be stated that the most optimal period for insemination of Polish Holstein-Friesian Black-and-White heifers is at the age of over 16 months or below 14 months (the latter being a less advantageous variant).

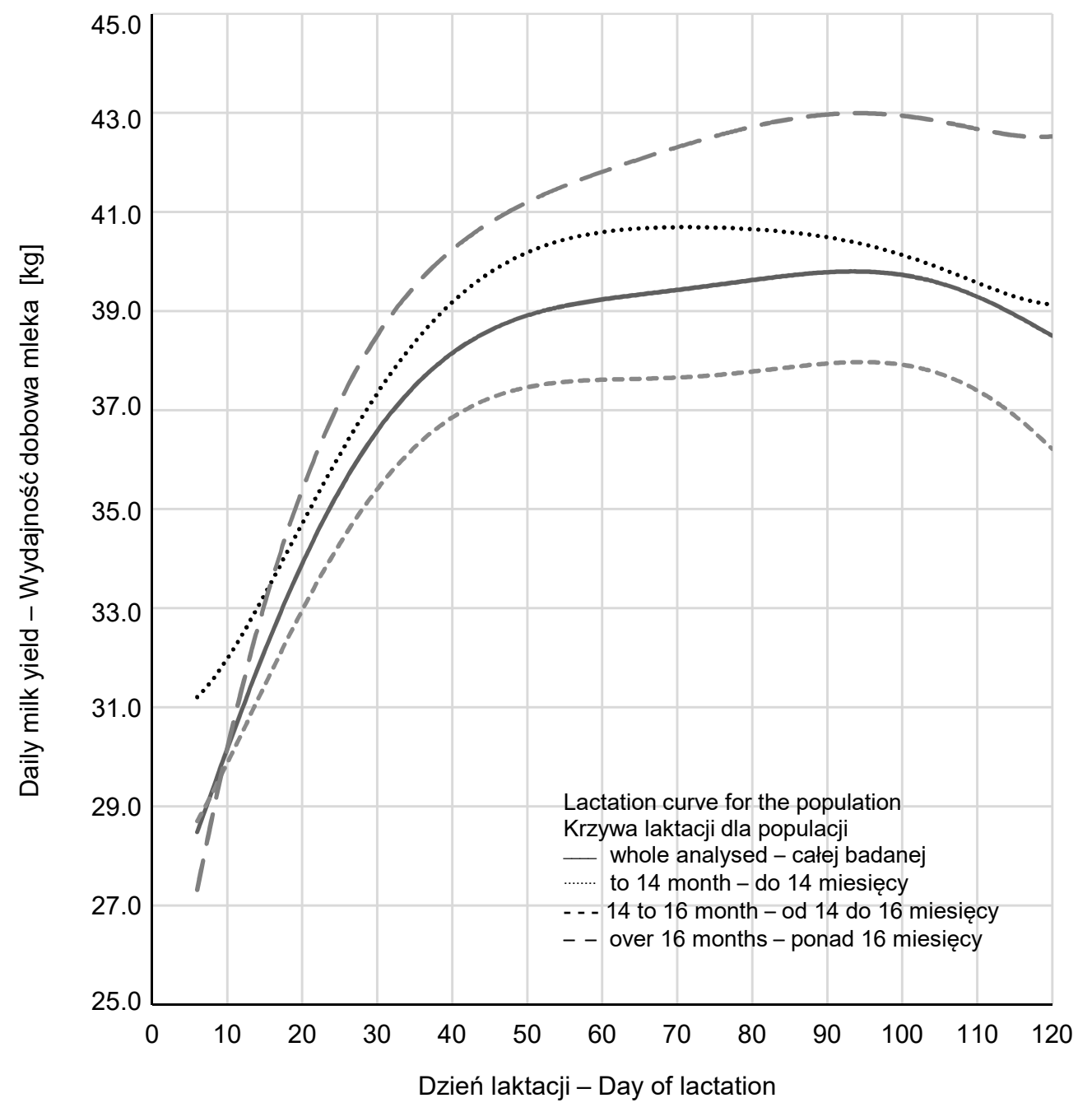

Fig. 2. Daily milk yield and the lactation curve for daily milk yield during the freshening period in primiparous Polish Holstein-Friesian Black-and-White cows in terms of age at first fertilization in their life Ryc. 2. Wydajność dobowa mleka i przebieg krzywej laktacji dla dobowej wydajności mleka w okresie rozdajania pierwiastek rasy polskiej holsztyńsko-fryzyjskiej odmiany czarno-białej przy uwzględnieniu wieku, przy pierwszym zacieleniu w ich życiu

Table 3 presented results concerning the effect of body weight of heifers at fertilization on milking performance traits in individual freshening stages and jointly in the period from day 6 to day 120 of lactation. 
Table 3. Milk yields of primiparous Polish Holstein-Friesian Black-and-White during the freshening period (from day 6 to day 120 of lactation) in terms of body weight at first calving in their life

Tabela 3. Wydajność mleczna pierwiastek rasy polskiej holsztyńsko-fryzyjskiej odmiany czarno-białej w okresie rozdajania (od 6 do 120 dnia doju), przy uwzględnieniu masy ciała przy pierwszym zacieleniu w ich życiu

\begin{tabular}{|c|c|c|c|c|c|c|c|c|c|c|c|c|c|}
\hline \multirow{3}{*}{$\begin{array}{c}\text { Period of } \\
\text { lactation } \\
\text { [days] } \\
\text { Okres } \\
\text { laktacji } \\
\text { [dni] }\end{array}$} & \multirow{3}{*}{$\begin{array}{c}\text { Traits } \\
\text { Cechy } \\
{[\mathrm{kg}]}\end{array}$} & \multicolumn{12}{|c|}{$\begin{array}{l}\text { Body weight at first fertilization } \\
\text { Masa ciała przy pierwszym zacieleniu [kg] }\end{array}$} \\
\hline & & \multicolumn{4}{|c|}{$\leq 425,0$} & \multicolumn{4}{|c|}{$425,1-475,0$} & \multicolumn{4}{|c|}{$>475$} \\
\hline & & $\bar{x}$ & SD & $\min$ & $\max$ & $\bar{x}$ & SD & $\min$ & $\max$ & $\bar{x}$ & SD & $\min$. & $\max$ \\
\hline & $\begin{array}{c}\text { daily milk yield } \\
\text { dobowa wydajność mleka }\end{array}$ & $33.0 \mathrm{~A}$ & 7.7 & 7.4 & 52.7 & $32.4 \mathrm{~B}$ & 7.9 & 8.2 & 57.3 & $34.5 \mathrm{AB}$ & 7.7 & 8.9 & 57.9 \\
\hline $6-30$ & $\begin{array}{l}\text { total milk yield } \\
\text { tączna wydajność mleka }\end{array}$ & 824.1 & 158.5 & 358.2 & 1168.1 & 810.1 a & 154.4 & 368.4 & 1211.1 & $861.5 \mathrm{a}$ & 144.6 & 588.3 & 1161.7 \\
\hline & $\begin{array}{c}\text { daily milk yield } \\
\text { dobowa wydajność mleka }\end{array}$ & $37.9 \mathrm{~A}$ & 7.2 & 12.0 & 56.3 & $38.3 \mathrm{~B}$ & 8.0 & 16.3 & 60.0 & $39.7 \mathrm{AB}$ & 8.1 & 11.8 & 64.5 \\
\hline $31-60$ & $\begin{array}{c}\text { total milk yield } \\
\text { łączna wydajność mleka }\end{array}$ & $1136.9 \mathrm{a}$ & 190.5 & 555.3 & 1500.5 & $1148.4 \mathrm{a}$ & 219.9 & 726.8 & 1533.5 & $1190.2 \mathrm{a}$ & 215.0 & 700.4 & 1708.3 \\
\hline & $\begin{array}{c}\text { daily milk yield } \\
\text { dobowa wydajność mleka }\end{array}$ & $32.9 \mathrm{~A}$ & 7.3 & 10.8 & 57.6 & $39.1 \mathrm{~B}$ & 8.7 & 15.9 & 62.9 & $41.3 \mathrm{AB}$ & 7.5 & 18.1 & 64.8 \\
\hline $61-90$ & $\begin{array}{c}\text { total milk yield } \\
\text { łączna wydajność mleka }\end{array}$ & 1174.7 & 184.7 & 509.7 & 1550.6 & $1172.7 \mathrm{a}$ & 233.2 & 725.6 & 1561.6 & $1238.0 \mathrm{a}$ & 195.9 & 762.7 & 1661.7 \\
\hline & $\begin{array}{c}\text { daily milk yield } \\
\text { dobowa wydajność mleka }\end{array}$ & $38.9 \mathrm{~A}$ & 7.4 & 9.9 & 66.8 & $38.6 \mathrm{~B}$ & 8.8 & 14.2 & 61.2 & $41.9 \mathrm{AB}$ & 8.4 & 14.5 & 69.6 \\
\hline $91-120$ & $\begin{array}{c}\text { total milk yield } \\
\text { łączna wydajność mleka }\end{array}$ & $1166.8 \mathrm{a}$ & 175.4 & 546.0 & 1523.1 & $1156.5 b$ & 233.1 & 672.5 & 1627.7 & $1255.6 a b$ & 223.6 & 726.5 & 1818.3 \\
\hline & $\begin{array}{c}\text { daily milk yield } \\
\text { dobowa wydajność mleka }\end{array}$ & $37.4 \mathrm{~A}$ & 7.8 & 7.4 & 66.8 & $37.3 \mathrm{~B}$ & 8.8 & 8.2 & 62.9 & $39.5 \mathrm{AB}$ & 8.4 & 8.9 & 69.6 \\
\hline $6-120$ & $\begin{array}{c}\text { total milk yield } \\
\text { łączna wydajność mleka }\end{array}$ & $4302.5 a$ & 639.4 & 1969.2 & 5645.6 & $4287.7 \mathrm{~b}$ & 782.6 & 2560.4 & 5669.6 & $4545.4 a b$ & 705.4 & 2789.9 & 5975.9 \\
\hline
\end{tabular}

Means with the same letter (in rows) differ: $A, B, C(p \leq 0.01) ; a, b, c(p \leq 0.05)-$ Średnie oznaczone tymi samymi literami ( $w$ wierszach) różnią się: $A, B, C \quad(p \leq 0,01)$; $a, b, c(p \leq 0,05)$ 
Statistical verification showed a significant effect of body weight of cows at fertilization on their daily milk yields $(P \leq 0.01)$ in the investigated stages of lactation and throughout the period from day 6 to day 120 of lactation. In the case of total milk yields in the analyzed lactation periods and over the entire freshening period this dependence was observed at $P \leq 0.05$. Heifers, which at fertilization had the greatest body weight $(>475 \mathrm{~kg})$, as primiparous cows were characterized by the highest daily milk yields as well as total milk yields both in the four analyzed phases of lactation and over the entire freshening period. This group of animals in terms of the investigated milking performance traits differed from the two other populations of cows, which were fertilized at a lower body weight ( $<425 \mathrm{~kg}$ and $425.1-475.0 \mathrm{~kg})$. No statistical significant differences were recorded for milk yields between the two groups of cows with the lowest body weights at fertilization. In view of lactation curves plotted for daily milk yield during freshening in primiparous cows with varied body weight at fertilization (Fig. 3) it may be stated that it is advisable to inseminate heifers at a body weight over $475 \mathrm{~kg}$. Daily milk yields comparable to those of the mean population were recorded for the group of cows effectively inseminated at a body weight of max. $425 \mathrm{~kg}$.

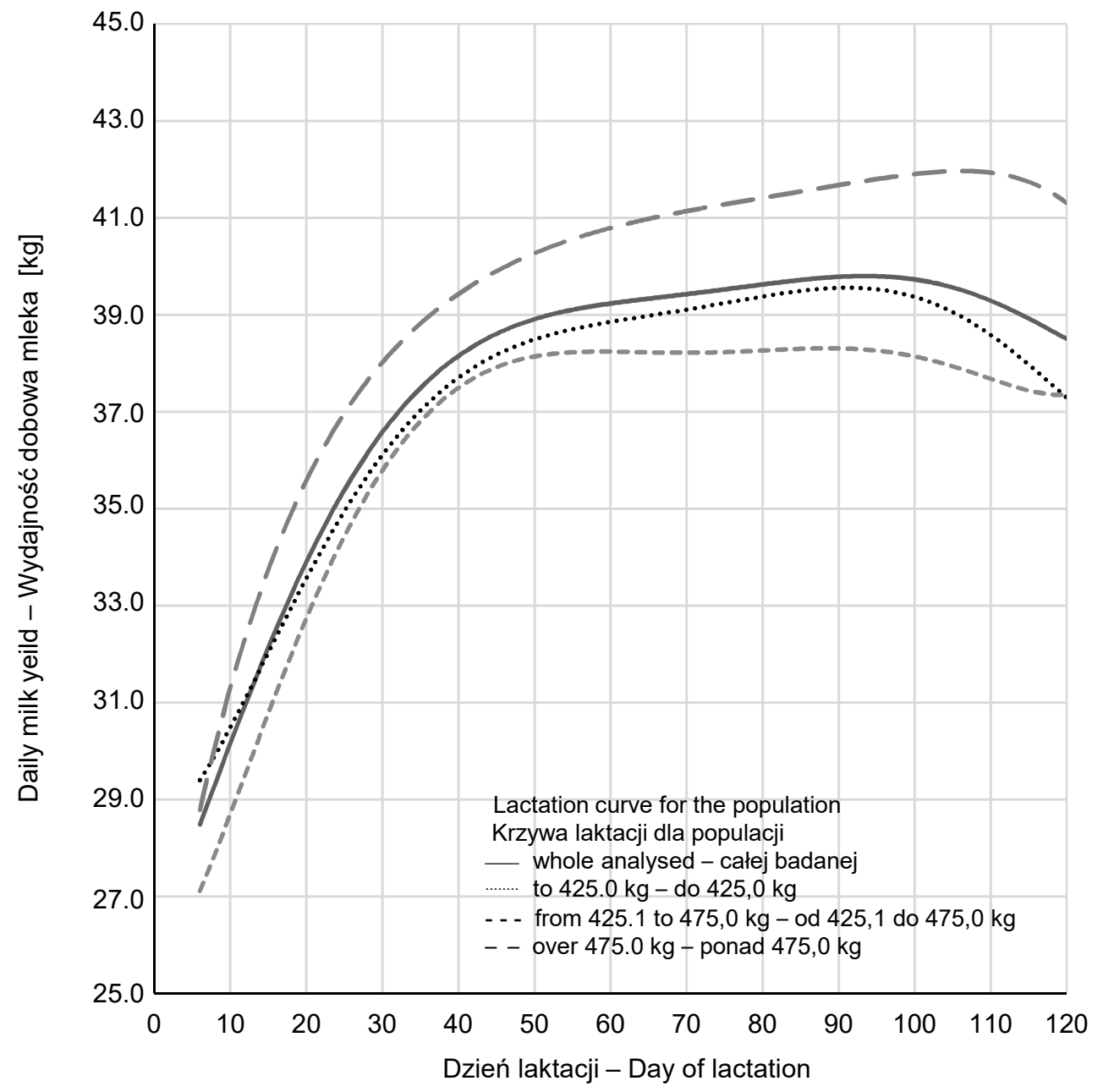

Fig. 3. Daily milk yield and the lactation curve for daily milk yield in the freshening period in primiparous Polish Holstein-Friesian Black-and-White cows in terms of body weight at first fertilization in their life Ryc. 3. Wydajność dobowa mleka i przebieg krzywej laktacji dla dobowej wydajności mleka w okresie rozdajania pierwiastek rasy polskiej holsztyńsko-fryzyjskiej odmiany czarno-białej, przy uwzględnieniu masy ciała przy pierwszym zacieleniu w ich życiu 


\section{DISCUSSION}

In this study the most advantageous results concerning milk yields in individual lactation periods and throughout the freshening period (from day 6 to day 120 of lactation) were recorded for primiparous cows sired by bulls from North America. In a study by Antkowiak et al. (2009) no significant differences in milk yields in the 100-day lactation were observed between daughters of bulls originating from the USA, France and Canada. In turn, in studies conducted by the same authors and concerning milk yields of primiparous cows in the 305-day lactation the most advantageous results were recorded for daughters of bulls from the USA.

In another study by Antkowiak et al. (1998) the highest milk yields in the 100-day lactation were reported for daughters of bulls from France in comparison to primiparous cows sired by bulls from Germany, Sweden and Poland. In another study Dymnicki and Reklewski (1999) showed that primiparous daughters of Holstein bulls from Italy in terms of their milk yield, fat and protein contents were superior to the populations of cows sired by bulls from Germany, France, Hungary and Poland. Observations reported by Brzozowski and Zdziarski (2006) conducted in Poland confirmed the opinion that daughters sired by imported bulls in comparison to the progeny of sires originating from Poland are characterized by a greater productivity potential in terms of milk and protein yields, which most probably results from their high breeding value estimated for milking performance traits. However, a significant factor influencing performance traits is connected with the homogeneous production environment rather than the country of origin (Zwald et al. 2003).

In turn, the primary aim for the establishment of Interbull was connected with the mission for development and standardization of breeding value for dairy cattle (Brotherstone and Goddard 2005). The greater milk yield of daughters sired by bulls from North America, recorded in this study, may result from the improvement of domestic environmental conditions related with milk production, as well as the longest upgrading period of Holstein-Friesian cattle for milking performance traits in comparison to the European dairy cattle breeds. Considerable export levels of both HF animals and semen from North America to Europe were recorded in the years 1970-1990 (Funk 2006).

It is commonly known that factors determining fertilization of heifers include their age and body weight. The most significant element is related with the optimal development of organism, which determines the physiological progression of pregnancy, has no negative effect on the health status of young females and promotes the maximum milk yield after calving. Numerous studies have shown that in order to obtain higher milk yields by primiparous cows already calves need to be fed large doses of milk (approx. 10 liters/day).

Khan et al. (2011) suggest that an increase in milk intake stimulates the immune system of animals and is connected with increased milk yields in primiparous cows. In the opinion of Akins (2016), improved profitability of dairy farms is promoted by intensive milk feeding of calves. Rincker et al. (2011) when conducting studies on Holstein cattle found that intensified calf feeding may be applied in order to reduce the age at first calving with no negative effect on milk yield and economics of milk production. Soberon et al. (2012) showed that an increased growth rate of heifers has a positive effect on their future milk yields. Investigations conducted by the authors of this study showed the most advantageous milk yield parameters 
for heifers inseminated at the age $>16$ months. This was most probably connected with the greater body weight reached by heifers in that period of life as well as a more advanced body development.

In the opinion of Mohd Nor et al. (2013) fertilization of younger heifers with no changes in the feed ration guaranteeing adequate body development reduces their milk yields in the first lactation, while differences in the age at first calving result from herd variation in terms of their nutrition regimes. Ettema and Santos (2004) showed that in the USA from the economic point of view the most advantageous age at first calving in primiparous Holstein cows is 23-24.5 months. In another study Krpálkova et al. (2014a) found no negative effect of a young age at first calving ( $\leq 699$ days) on milk production and reproduction. However, in a different study Krpálkova et al. (2014b) suggested that a younger age at first calving ( $\leq 749$ days) is not always profitable, as it is determined by the herd management standard. Archobold et al. (2012) reported that the age of heifers at successful insemination is not reflected in their later milking performance, while milk yield is influenced by the adequate body development. Age at first calving is dependent on the growth rate of heifers (Bourne et al. 2008). Heifers with a greater body weight at fertilization as a rule are characterized by greater growth rates. In this study it was found that heifers with the greatest body weight at fertilization had the greatest milk yields. This is most probably connected with the positive correlation showed by Hoffman (1997) between body weight at calving and zoometric parameters, and milk yields of primiparous cows. According to Wathes et al. (2014), body weight of heifers is significant in the maturation period and at first calving, while it also influences milk yields of primiparous cows; in contrast, this factor is not related with milking performance of cows in successive lactations.

\section{CONCLUSIONS}

1. A statistically significant effect of the origin of sire as well as the age and body weight at fertilization of heifers was shown on the freshening efficiency in primiparous Polish Holstein-Friesian Black-and-White cows.

2. The greatest milk yields during the freshening period were recorded for daughters of bulls coming from North America and primiparous cows, which were fertilized as heifers aged $>16$ months and at body weight $>475 \mathrm{~kg}$.

3. Most probably the high genetic potential of HF cattle from North America, exceeding European cattle in terms of milk yield, was connected with the longer upgrading period, which in combination with the improvement of local production conditions ensured the most advantageous results.

4. It seems that milk yield in the freshening period is influenced to a greater degree by body weight and development of heifers rather than their age at fertilization. In order to reduce the rearing phase in young female cows it is recommended to apply more intensive feeding regimes.

\section{REFERENCES}

Akins M.S. 2016. Dairy heifers development and nutrition management. Vet. Clin. North. Am. Food Anim. Pract. 32, 303-317.

Antkowiak I., Dorynek Z., Kliks R. 1998. Wpływ buhajów z niektórych hodowli europejskich na użytkowość bydła w Wielkopolsce, w: Uwarunkowania produkcji mleka wysokiej jakości. Materiały konferencyjne, Dłoń 24-25 września 1998 r. Poznań, Wydaw. AR, 13-17. [in Polish] 
Antkowiak I., Pytlewski J., Skrzypek R., Jakubowska M. 2009. Wpływ pochodzenia buhajów na użytkowość mleczną córek [The effect of provenance of bulls on milking performance of their daughters]. Rocz. Nauk. PTZ 5(4), 11-19. [in Polish]

Archbold H., Shallo L., Kennedy E., Pierce K.M., Buckley F. 2012. Influence of age, body weight and body condition score before mating date on the puberal rate of maiden Holstein-Friesian heifers and implications for subsequent cow performance and profitability. Animal 6, 1143-1151.

Bourne N.E. Swali A., Cheng Z. 2008. Factors influency heifer survival and fertility on commercial dairy farms. Animal 2, 1135-1143.

Brotherstone S., Goddard M. 2005. Artificial selection and maintennance of genetic variance in the global dairy cow population. Philos. Trans. R. Soc. Lond., B Biol. Sci. 29,360 (1459), 1479-1488.

Brzozowski P., Zdziarski K. 2006. Wpływ wieku i sposobu użytkowania buhajów na wydajność mleczną ich córek [Influence of age and mode of use of bulls on their daughters' milk yield] . Med. Weter. 62, 960-962. [in Polish]

Dymnicki E., Reklewski Z. 1999. Użytkowość mleczna córek buhajów z niektórych krajów europejskich i krów importowanych z Niemiec i Holandii [Milk performance of daughters of top bulls from some countries and imported cows from Germany and Holland]. Zesz. Nauk. Prz. Hod. 44, 101-108. [in Polish]

Ettema J., Santos J.E. 2004. Impact of age calving on lactation, reproduction health and income in first panty Holstein on commercial farms. J. Dairy Sci. 87, 2730-2742.

Funk D.A. 2006. Major advances in globalization and consolidation of the artificial insemination industry. J. Dairy Sci. 89, 1362-1368.

Hoffman P.C. 1997.Optimum body size of Holstein replacement heifers. J. Dairy Sci. 75, 836-845.

Khan M.A., Weary D.M., Keyserling M.A. von. 2011. Invited review: Effects of milk ration on solid feed intake, weaning and performance in dairy heifers. J. Dairy Sci. 94, 1071-1081.

Krpálkova L., Cabrera V.E., Vacek M., Stipková M., Stadnik L., Crump P. 2014a. Effect of prepubertal and postpubertal growth and age at first calving on production and reproduction traits during the first 3 lactations in Holstein dairy cattle. J. Dairy Sci. 97, 3017-3027.

Krpálkova L., Cebrera V.E., Kvapilik J., Burdych J., Crump P. 2014b. Associations between age at first calving, rearing average daily weigh gain, herd, milk yield and dairy herds production reproduction and profitability. J. Dairy Sci. 97, 6573-6582.

Mohd Nor N., Steeneveld W., Werven T. van, Mourits M.C., Hogeveen H. 2013. First calving age and first lactation milk production on dutch dairy farms. J. Dairy Sci. 96, 981-992.

Rincker L.E., Vandehaar M.J., Wolf C.A., Liesman J.S., Chapin L.T., Weber Nielsen M.S. 2011. Effect of intensified feeding of heifer calves on growth pubertal age, calving age, milk yield and economics. J. Dairy Sci. 94, 3554-3567.

SAS ${ }^{\circledR}$ user's guide. Statistics version 9.3 edition. 2015. Cary, NC, USA, SAS Institute.

Soberon F., Raffrenato E., Everett R.W., Amburgh M.E. van. 2012. Preweaning milk replacer intake and effects on long term productivity of dairy calves. J. Dairy Sci. 95, 783-793.

Wathes D.C., Pollot G.E., Johnson K.F., Richardson H., Cooke J.S. 2014. Heifers fertility and carry over consequences for life time production in dairy and beef cattle. Animal 1(Suppl.), 91-104.

Zwald N.R., Weigel K.A., Fikse W.F., Rekaya R.T. 2003. Application of a multipletrait herd cluster model for genetic evaluation of dairy sires from seventeen countries. J. Dairy Sci. 86, 376-382.

Abstract. Sire origin as well as age and body weight of heifers at fertilization were shown to have a statistically significant effect on freshening milking efficiency in Polish Holstein-Friesian Black-and-White primiparous cows. The highest milk yields during the freshening stage were recorded for daughters of bulls from North America and primiparous cows, which were fertilized as heifers aged $>16$ months and at body weight $>475 \mathrm{~kg}$. Most probably the high genetic potential of HF cattle from North America, exceeding European cattle in terms of milk yield, was connected with 
the longer period of their upgrading and in combination with the improvement of local production conditions ensured the most advantageous results. It seems that milk yield in the freshening period is affected by body weight and development of heifers rather than their age at fertilization. In order to reduce the rearing stage in young females it is recommended in that period to apply more intensive nutrition. 
